\title{
Health education in Aedes aegypti: case study
}

\author{
Educação em saúde sobre o Aedes aegypti: relato de experiência \\ Educación en salud en torno al Aedes aegypti: un reporte de experiencia
}

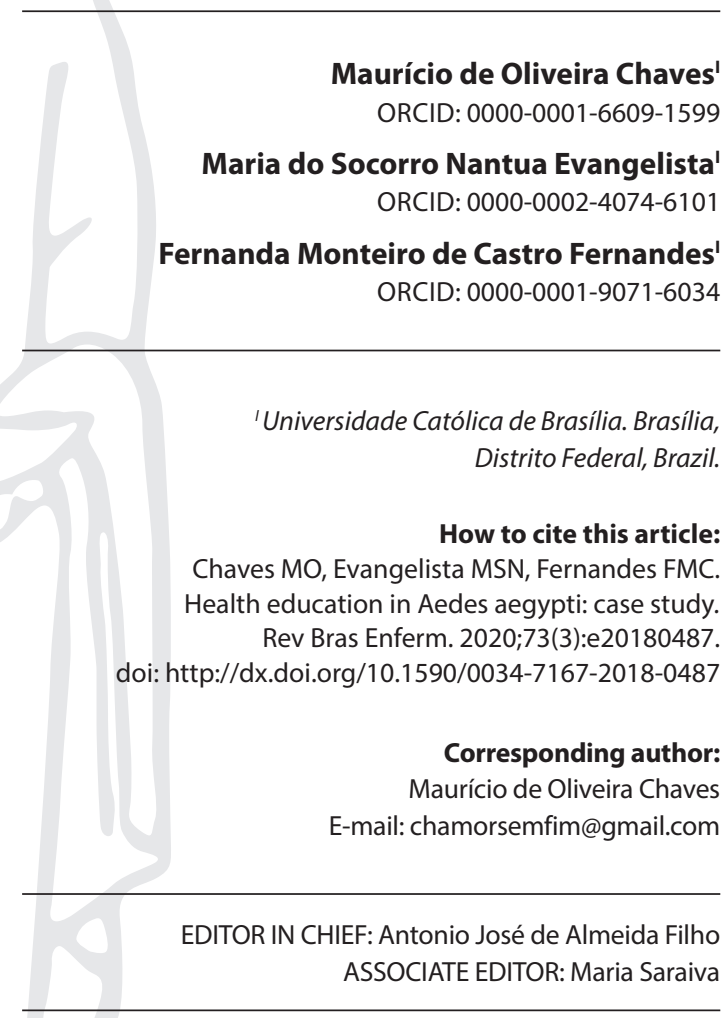

Submission: 06-09-2018 Approval: 04-06-2019

\begin{abstract}
Objectives: Reporting the experience of health education regarding Aedes aegyptiin the Federal District. Methods: This is a case report, with descriptive approach, about the experience of nursing practice with education actions against the Aedes aegypti in communities of the Federal District, carried out between 2015 and 2018. Subjects of the research were undergraduate students in nursing, healthcare professionals, and the community. Results: There have been 24 educational interventions against Aedes aegypti, adapted to the needs of each population, using a "giant" sculpture of the mosquito, theater performances, lectures, booklets, and home visits. Conclusions: The project trained teachers, healthcare professionals, graduate students in nursing, and the community through the empowerment of this population, aiming at combating the Aedes aegypti vector.

Descriptors: Aedes aegypti; Primary Healthcare Nursing; Innovation; Primary Prevention of the Disease; Health Education.
\end{abstract}

\section{RESUMO}

Objetivos: Relatar a experiência sobre educação em saúde em relação ao Aedes aegypti no Distrito Federal. Métodos: Trata-se de um relato de experiência, com abordagem descritiva, sobre a vivência da prática de enfermagem com ações educativas contra o Aedes aegypti em comunidades do Distrito Federal, realizada entre 2015 a 2018. Os sujeitos da pesquisa foram os graduandos de enfermagem, os profissionais dos serviços de saúde e a comunidade. Resultados: Realizaram-se 24 atuações educativas contra o Aedes aegypti, adaptadas às necessidades de cada público, utilizando-se uma escultura "gigante" do mosquito, apresentações de teatro, palestras, cartilhas e visitas domiciliares. Conclusões: $O$ projeto capacitou docentes, profissionais de saúde, graduandos de enfermagem e comunidade por meio do empoderamento dessa população, com vistas ao combate ao vetor Aedes aegypti. Descritores: Aedes aegypti; Enfermagem de Atenção Primária; Inovação; Prevenção Primária de Doença; Educação em Saúde.

\section{RESUMEN}

Objetivos: Reportar la experiencia en torno a la educación en salud relacionada con el Aedes aegypti en el Distrito Federal (Brasil). Métodos: Se trata de un reporte de experiencia, de abordaje descriptivo, sobre la vivencia de la práctica de enfermería con acciones educativas contra el Aedes aegypti en comunidades del Distrito Federal, realizado en el período entre 2015 y 2018. Participaron en este estudio los estudiantes del grado en enfermería, los profesionales de los servicios de salud y la comunidad. Resultados: Se realizaron 24 acciones educativas contra el Aedes aegypti, las cuales se adaptaron a las necesidades de cada público y se utilizó una escultura "gigante" del mosquito, presentaciones de teatro, charlas, cartillas y visitas domiciliarias. Conclusiones: El proyecto capacitó a los docentes, a los profesionales de salud, a los estudiantes de grado en enfermería y a la comunidad, por medio del empoderamiento para combatir el vector Aedes aegypti.

Descriptores: Aedes aegypti; Enfermería de Atención Primaria; Innovación; Prevención Primaria de la Enfermedad; Educación en Salud. 


\section{INTRODUCTION}

Epidemiological data on dengue, chikungunya, and zika in the Midwest region of Brazil feature high magnitude and, in 2016, the incidence of dengue was $1,065.9 / 100$ thousand inhabitants; of chikungunya, $6.6 / 100$ thousand inhabitants; and of zika, 189.7/100 thousand inhabitants. The Federal District, in 2016, registered 13,645 likely cases of dengue fever, an incidence of 458.3/100 thousand inhabitants; on the other hand, the incidence of chikungunya fever accounted for 10.4/100 thousand inhabitants; and the acute disease caused by the zika virus, 8.9/100 thousand inhabitants. In 2017, there was a significant reduction of cases of dengue fever in the Midwest, affecting about 160.0/100 thousand inhabitants. On the other hand, in the Federal District, dengue presented a $36.2 / 100$ thousand inhabitants incidence; chikungunya fever, $1.7 / 100$ thousand inhabitants; and the zika virus, $0.8 / 100$ thousand inhabitants ${ }^{(1)}$. In 2016, 17 deaths due to dengue fever were notified in the Federal District and, in 2017, there was no death. According to Vigilância Epidemiológica [Epidemiological Surveillance] program, these data indicate the seriousness of the problem, and, therefore, the need for innovative activities with the community in order to empower individuals regarding the conducts towards actions for preventing the proliferation of the Aedes aegypti vector, identification of symptoms, and early treatment of suspected cases. Among the proposed innovations, there should be given greater visibility to the expansion of surveillance and knowledge of the population about the problem. In this perspective, health education is a paramount tool in the learning process, since it increases people's autonomy to proactively act for solving their issues ${ }^{(2)}$.

Authors conceptualize health education as an educational process for acquiring knowledge - not only scientific, but also valuing popular knowledge and the prior knowledge of the individual, increasing people's autonomy to discuss, along with the healthcare professionals, ways to meet their real needs, being themselves the main transformer pieces ${ }^{(2-4)}$. Authors also emphasize the importance of health education in relation to the process of acquisition of the systematized technical and scientific knowledge for working in health, and teaching practices, highlighting the context and the permanent education for qualifying the working process, aiming to a better performance against the different experienced scenarios $^{(2,5-6)}$ on the part of healthcare professionals, managers, the overall population and undergraduate students in nursing.

In this sense, health education allows educators, in the context of the Brazilian Unified Health System (SUS), and particularly in Primary Health Care, to expand their worldview, urging all actors to work actively and innovatively. Innovating in health means having ideas, methods, or objects, or even recreating something in a unique manner; it means adding value generating effective actions. Considering the diversity of changes in the contemporary era, new ways for teaching and learning are required, demanding active subjects and entrepreneurs to use resources at their disposal to make decisions for solving problems ${ }^{(5)}$. In this sense, nurses play an important role in health education, considering their skills and competencies developed over their professional practice and in academia, when (re)inventing and (re)producing knowledge in a personalized way, establishing a reflective dialogue with patients in such a way to make them aware of the importance of their active participation to transform their health and lives, empowering them as individuals, users ${ }^{(2)}$, and citizens.

Additionally, the particularity of the ethical involvement of healthcare professionals, managers, and users of the healthcare network in educational practices makes such assistance meeting one of the fundamental principles of SUS: the completeness of health care $^{(7)}$. On its turn, health education gathers scientific practices and contents discussed in academia and allows their insertion in SUS, through training of nurses and professionals that meet the demand for healthcare services. Therefore, the teaching-service articulation perceives and brings the improvement of the assistance to users, in order to adequately meet their needs, which, in its turn, establishes the training and permanent education process of healthcare professionals, seeking to consolidate the implementation of a welcoming, comprehensive, committed, and socially fair SUS ${ }^{(5,7)}$.

Considering the epidemiological scenario and the seriousness of the issue of dengue, chikungunya, and zika diseases in the Federal District, and given the ease of insertion and the expertise of a nursing program in being engaged in the creation of new strategies for facing these diseases, and the need for creating new experiences in health education on the issue, an innovative proposal was carried out, involving several actors (nursing students, teachers, managers, and healthcare professionals) and scenarios (schools, hospitals, ambulatory, enterprises). The question is whether health education about emerging themes, when approached creatively and in a differentiated way, causes the engagement of those involved in the action. Was health education a motivating tool for innovating educational practices? How to awaken the critical-reflective thinking of future healthcare professionals and the overall population about given problem? That is, it is a process of complex, self-directed, and systematic reasoning, which favors the choice of the best conducts for solving nursing problems within the context in which they are inserted, allowing professionals to work from the cognitive, experimental, and intuitive point of view, while respecting the ethical precepts of the profession ${ }^{(8)}$.

\section{OBJECTIVES}

Reporting the experience of health education in relation to Aedes aegypti in the Federal District.

\section{METHODS}

This is a case report with descriptive approach. Health education actions involving Aedes aegypti were developed in eight Administrative Regional Offices of the Federal District, namely: Águas Claras, Gama, Ceilândia, Itapoã, Setor Complementar de Indústria e Abastecimento [Complementary Sector for Industry and Supply], Taguatinga, Recanto das Emas, and Brasília, between 2016 and 2018. These locations were selected for having a higher incidence of dengue, chikungunya, and zika, and also greater access to schools and managers of healthcare services.

In the period of operation of the project, 24 educational actions were carried out, 14 in 2016; 8 in 2017; and 2 in 2018. As for the several locations where we conducted the experience, responsible authorities from all places authorized running the project. The locations included universities, healthcare centers, university libraries, 
education and kindergarten centers, private education centers, squares, global actions, public roads, urban and rural communities, private traffic companies, and public agencies for epidemiological surveillance of regional offices. Among the participants of the activities, we included about 170 healthcare professionals; 350 employees of a private traffic company; 300 people from a rural community; 89 undergraduate students in nursing; 1,800 college students; 1,350 people from the school community; 7,125 people from communities; 4,500 patients of healthcare centers; 880 elementary-school students; and 77 teachers of early childhood education. In addition, there were 1,602 views of the project video available from YouTube, with a total of 18,243 people involved in the project.

\section{Assembling the sculpture of Aedes aegypti to promote health education}

For the implementation of educational activities focusing on prevention of diseases transmitted by Aedes aegypti, we made a giant and anatomical sculpture of the female mosquito, with 2 meters high and 6 meters in length, on a magnification scale of 850:1. The sculpture displayed external and internal organs, locations the virus travels in vector (labrum, hypopharynx, antennae, compound eye, salivary gland, internal ducts, abdomen, and ovipositor), detailing from mouthparts to reproductive organ, aiming to explain the full cycle and the determinant elements of the life of the virus within its organism.

The sculpture was developed in iron, steel screens, and PVC fabrics, over seven months. After finishing it, we could start the actions aiming at building a healthier coexistence of individuals and the social group, inproving differentiated healthcare practices, scientifically relevant, and economically viable ${ }^{(3)}$.

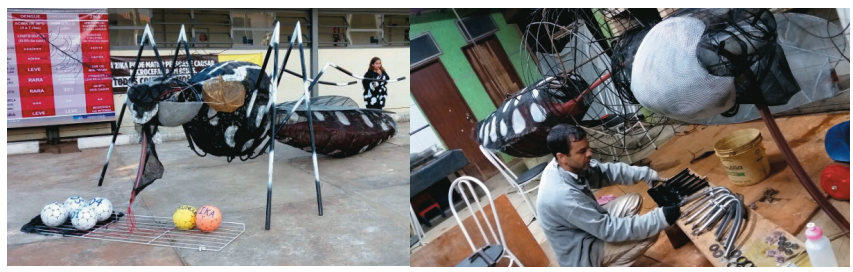

Figure 1 - Images of the anatomical sculpture of the Aedes aegypti mosquito

\section{Methodological creation}

The strategy of health education included the exhibition of the giant sculpture of Aedes aegypti in the locations with interactive lectures, with demonstration of the mosquito in its different life-cycle stages, theater presentations, handing out booklets, walks, home visits, characters dressed as the mosquito, answering questions, instructions on how to extinguish potential breeding sites and the elimination of breeding sites. The next step was the local training and motivation of the team for the development of the experiment. In this step, we count on the support of the following actors: teachers, nursing students, healthcare professionals, and managers.

\section{Teachers' training}

Initially, as justification of the project, we needed to expand the surveillance on the proliferation of Aedes aegypti and the diseases transmitted by it, aiming at improving the actions and encouraging nursing students to reflect on the matter, in order to optimize strategies for the implementation of the theme in healthcare services. As a theoretical reference, we used several scientific articles, recommendations of the Brazilian Ministry of Health, entomological studies on anatomy and physiology of the Aedes aegypti mosquito, selection of photomicrographs of the mosquito to qualify the agents regarding aspects of the three-dimensional anatomical structure of the vector, in addition to surveying the main sensory and motion structures, related to vision, heat, and respiratory gases - in this case, with the support of the consulting of the Board of Environmental Health Surveillance of the Federal District [Diretoria de Vigilância Ambiental em Saúde do Distrito Federal]. In this experiment, five professors of the Program in Nursing from Universidade Católica de Brasília (UCB) participated in the training.

These contents and the form of including the new methodology in the creation of the proposal comprises the permanent education for the educator professional, enabling new opportunities to educate and learn ${ }^{(7)}$. The search for new skills instigates the critical and creative capacity of subjects, allowing professionals to develop new work perspectives in health for achieving a multidimensional education, considering a concrete and contextualized performance in such a way praxis produces changes ${ }^{(6)}$ and the education of a holistic being ${ }^{(3)}$. This search also helps in the education of professionals seeking skills and abilities to coexist with diversity, being creative in the intervention process, and adding value regarding technological advances ${ }^{(9)}$.

Mostly, as university educators, professors must prioritize the education of healthcare professionals committed to social demands, able to reflect on their social reality, and develop transformative actions, with the continuous commitment to improve knowledge ${ }^{(4)}$, in accordance with the nursing syllabus.

\section{Training of undergraduate students}

There were 52 undergraduate students in nursing, from the UCB Program in Nursing, attending the training program. These students were taking the compulsory course in Internship in Community Health of the seventh semester of the nursing program, and such training was part of the proposed syllabus of the regular semester of the undergraduate program. Training of the students was held in 8 hours, with the objective of motivating them concerning the issue related to Aedes aegypti and of broadening their knowledge on the subject, including the creation and development of new strategies, in addition to producing scientific literature and educational materials. The methodology included reading and roundtable; subsequently, components of the proposal were distributed based on the themes to be addressed: diseases transmitted by Aedes aegypti; clinical symptomatology; laboratory tests; control of breeding sites of vectors; differential diagnosis; treatment; complications (dengue hemorrhagic fever, microcephaly, death, among others); cycle of the virus in mosquitoes and human beings; advances in the production of vaccines against dengue fever; main elements related to the maintenance of breeding grounds; visits to the Health Inspectorate of the Federal District, in order to 
motivate them concerning the morphological differentiation between Aedes aegypti, Culex, and Aedes albopictus; completion of the compulsory notifications; geolocation of spots; as well as preventive and educational actions developed by the sector in the main spots of the vector.

In this sense, we understand that healthcare professionals are agents that develop educative actions in health, aiming to promote more satisfactory living conditions for the users, being nurses the professionals who often play this role with the population. Therefore, nursing professionals must adopt different approaches, including the questioning ones, which instigate innovative and transformative practices and, thus, think about the best strategies for organizing the process of healthcare work, considering the multiple social determinants of the local health care ${ }^{(4)}$.

\section{Describing the experience of the training of healthcare professionals}

In addition, 31 healthcare professionals working in SUS services were also qualified by the teacher in charge of the project. These healthcare professionals were qualified through participation in the actions, since they were the interlocutors of actions developed in the lectures and discussions on the subject, exhibitions, observation of approaches, community guidelines, and distribution of educational materials. Similarly, they participated in the collection of diagnostic, clinical, and laboratory tests, and in the active search for suspected cases of the disease and breeding grounds for mosquitoes. In this case, the articulation with other healthcare agencies was enabled such as the Environmental Surveillance [Vigilância Ambiental] and the Epidemiological Surveillance [Vigilância Epidemiológica]. It is noteworthy the importance of the multisector work process within the context of dengue, in which health education is crucial for everyone in in the same location to develop skills for achieving the best quality assistance, increasing the satisfaction of users and professionals, involving various groups (Government, private sector, and civil society) and sectors (health, environment, and economic) of stakeholders, strengthening bonds, and reducing fragmentation of efforts to produce better health outcomes ${ }^{(10)}$.

In this sense, professionals are able to broaden their resolutive capacity when facing problems identified in their daily practice, recognizing that knowledge is always temporary, and must be constantly acquired aiming at the completeness of health care ${ }^{(6)}$. Moreover, the need for professionals to continually update their technical and scientific knowledge is paramount for them to work according to the identified needs, based on their personal and professional experiences ${ }^{(2)}$.

\section{Health education in schools}

Actions developed in schools were programmed and planned in advance together with the local board and coordination, through prior contact to to know the space, the available time, the age group, and the amount of students. Later, there was a meeting with undergraduate students in nursing for structuring actions for the target audience. Institutions were responsible for introducing the theme "dengue, chikungunya, and zika" with educational activities in the classroom and, in a second moment, the health team put into practice the activities planned for further clarification and fixation of the knowledge, by lectures, characters dressed as the mosquito, theater presentations, group-interaction dynamics, questions and answers, distribution of educational material, exhibition of the sculpture, and visualization of the evolutionary phases of the mosquito in real samples.

In this case, when addressing health education with children, we can enhance their knowledge and skills. We could also insert the individuals in the social, ethical, and ideological context of their reality, allowing the diffusion and reflection of ideas among them, showing that there is no right age to educate, and that education is for their whole life ${ }^{(2)}$.

\section{Health education in the community}

Actions in the community were developed considering the specific aspects of each location. We organized events, in which the sculpture of the mosquito was exposed to call attention of the target audience, and in which instructions were given on the main signs and symptoms of the disease and how to fight breeding grounds inside their homes and outside. In these events, booklets and flyers on the theme were distributed, in addition to exposing the phases of the life cycle of the mosquito, from the eggs to the winged forms.

In some situations we paid visits in locations of greater vulnerability for the elimination of breeding grounds, associated with educational activities with the locals about the importance of individual and collective actions in the fight against the proliferation of Aedes aegypti and the reduction of diseases transmitted by it. These activities were developed together with local healthcare professionals and the community, aiming at the exchange of experiences and redeveloping habits of the population in question.

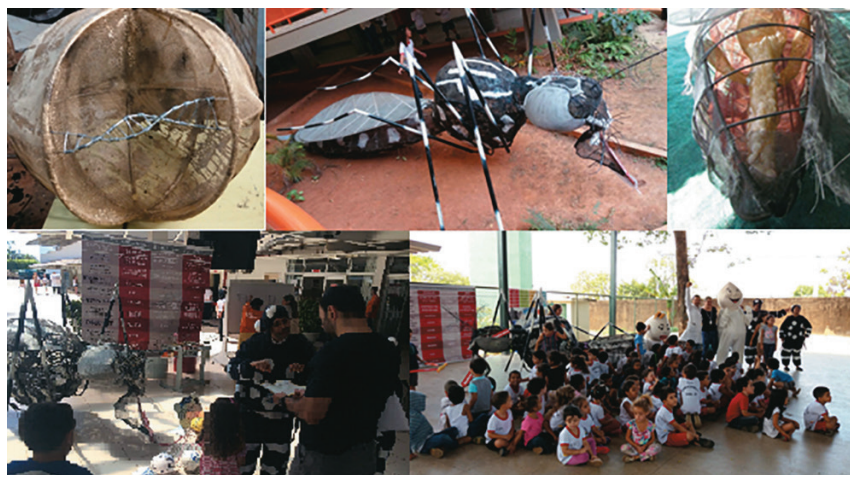

Figure $\mathbf{2}$ - Images of the actions with the anatomical sculpture of the Aedes aegypti mosquito

According to authors, in nursing educational practices constitute an important role in the health work, especially in the context of primary health care. Nurses, historically, develop the role of educator in the community, being present with their actions in different spaces such as the very healthcare service, schools, community associations, and other social groups ${ }^{(3)}$. Therefore, it was important for nursing students to experience this professional practice, since it could encourage the protagonism of subjects 
involved in educational activities, respecting their cultural universe, and understanding that these subjects are able to produce individual and collective changes from the shared creation of knowledge between them and the nurses. Hence, we perceived, in the practice of health education, that healthcare professionals should enhance the local reality, using a language accessible to the target audience, working for the deconstruction of concepts and behaviors of individuals, planning their educational activities always in an updated manner regarding a particular topic, and analyzing the effectiveness of the developed educational process, as proposed by Souza et al. ${ }^{(3)}$.

To do so, we must relate the common sense/popular knowledge to the scientific knowledge, from the interaction of subjects involved in a common interest, as an element for social transformation. We believe that educating is a broad action, which presupposes an active participation of the educated subject, emphasizing the importance of developing a health education practice with the involved subjects, promoting the exchange of experiences and knowledge between healthcare professionals and the population ${ }^{(2)}$, and providing subsidies to the incorporation of health habits ${ }^{(3)}$.

\section{Health education in the social network and project awards}

When arousing curiosity and calling attention of users of social networks, the project was disclosed and shared as a video through Facebook, YouTube, and WhatsApp.

In 2016 there was a contest of Department of Continuing Education, Literacy, Diversity, and Inclusion (Secretaria de Educação Continuada, Alfabetização, Diversidade e Inclusão - Secadi), in partnership with the Brazilian Ministry of Education (MEC), concerning health education practices. The project, titled Conhecimento sem ação, não acaba com o mosquito, não [Knowledge without action does not eradicate the mosquito], was submitted and, on November 8, 2016, it was awarded at the national level in the category "Private institution of higher education."

\section{Study limitations}

Limitations refer to transport and handling of the Aedes aegypti sculpture in some places, considering the size of the prototype; the lack of resources to develop and even broaden the project; the high turnover of students, who must be qualified before working in the project; difficulty in access to remote locations; dependence on the availability of volunteers to work in the project on weekends; availability of time concerning other activities carried out during the same term; and the lack of means to assess how much the actions developed in the communities have contributed to reducing the incidence of diseases.

\section{Contributions to the field of nursing}

Health education is a tool that strengthens the work of nurses with the community, focusing on making individuals the transformer pieces of their own reality. In addition, it stimulates nursing professionals beyond assistance-related matters, when enabling the creative practice of differentiated strategies for approaching new and/or commonplace topics, in order to stimulate the interest of the community to actively participate in health actions for improving quality of life. Health education also contributes to the qualification of new healthcare professionals, expanding their skills and abilities to deal with a disease that is present in the community. The recognition and reward of nursing professionals in the developed actions increase classroom dynamics in an innovative manner and, from the perspective of health organizations, it encourages the commitment for improving the provided services.

\section{FINAL CONSIDERATIONS}

The diseases dengue fever, zika, and chikungunya, transmitted by the Aedes aegypti mosquito, represent a public health issue in the Federal District, which requires increased surveillance and awareness of the population about the importance of fighting the vector. In this context, health education is essential to increase nursing actions in healthcare services and among the population. It is worth noting that the described action contributed to improve the practice of nursing education, developing, for professional nurses, skills and competencies based on their experiences, in which knowledge acquired in practice is used for solving problems. From this strategy, we could broaden the training of students and managers of services with an environmental interface, that is, dialoguing with other sectors. The developed activities also enabled to motivate the very healthcare service in recognizing the importance of continuous training for all professionals. Moreover, it is noteworthy that the performed actions strengthened multisector bonds.

\section{REFERENCES}

1. Distrito Federal (BR). Informativo Epidemiológico de Dengue, Chikungunya e Zika. Bol Epidemiol[Internet]. 2017 [cited 2018 Jul 25];48(14):[10 p.]. Available from: http://portalarquivos2.saude.gov.br/images/pdf/2017/maio/05/Monitoramento-dos-casos-de-denguefebre-de-chikungunya-e-febre-pelo-virus-Zika-ate-a-Semana-Epidemiologica.pdf

2. Falkenberg MB, Mendes TPL, Moraes EP, Souza EM. Educação em saúde e educação na saúde: conceitos e implicações para a saúde coletiva. Ciênc Saúde Colet [Internet]. 2014 [cited 2018 Jul 26];19(3):847-52. Available from: http://www.scielo.br/pdf/csc/v19n3/1413-8123-csc-19-03-00847.pdf

3. Souza IVB, Marques DKA, Freitas FFQ, Silva PE, Lacerda ORM. Educação em saúde e enfermagem: revisão integrativa da literatura. Rev Ciênc Saúde [Internet]. 2013 [cited 2018 Jul 28];1 1(1):112-21. Available from: http://www.facene.com.br/wp-content/uploads/2010/11/Educa\%E2 \%94\%9C\%C2\%BA\%E2\%94\%9C\%C3\%BAo-em-sa\%E2\%94\%9C\%E2\%95\%91de-e-enfermagem.pdf

4. Colomé JS, Oliveira DLLC. Educação em saúde: por quem e para quem? a visão de estudantes de graduação em enfermagem. Texto Contexto Enferm [Internet]. 2012 [cited 2018 Jul 29];21(1):177-84. Available from: http://www.scielo.br/pdf/tce/v21n1/a20v21n1.pdf 
5. Azevedo IC, Silva GWS, Vale LD, Santos QG, Cassiano NA, Morais IF, et al. Educação continuada em enfermagem no âmbito da educação permanente em saúde: revisão integrativa de literatura. Rev Saúde Pesqui [Internet]. 2015 [cited 2018 Jul 25];8(1):131-40. Available from: https://www.researchgate.net/publication/281433710_Educacao_Continuada_em_Enfermagem_no_Ambito_da_Educacao_Permanente_ em_Saude_Revisao_Integrativa_de_Literatura

6. Salum NC, Prado ML. A educação permanente no desenvolvimento de competências dos profissionais de enfermagem. Texto Contexto Enferm [Internet]. 2014 [cited 2018 Jul 29]23(2):301-8. Available from: http://www.scielo.br/pdf/tce/v23n2/pt_0104-0707-tce-23-02-00301.pdf

7. Jesus $A F$, Ribeiro ER. Educação na área da saúde: importância da atuação do enfermeiro. Caderno Saúde Desenvolv [Internet]. 2013 [cited 2018 Jul 28];3(2):[15 p.]. Available from: https://www.uninter.com/revistasaude/index.php/cadernosaudedesenvolvimento/article/ view/202/167

8. Becerril LC, Talavera BEM, Gómez BA, Rojas AM. Desarrollo del pensamiento reflexivo y crítico en estudiantes de enfermería: evidencia de una universidad pública mexicana. Rev Urug Enferm [Internet]. 2017 [cited 2018 Aug 2];12(1):[19 p.]. Available from: https://proceedings. ciaiq.org/index.php/ciaiq2015/article/view/284/280

9. Sade PMC, Peres AM. Development of nursing management competencies: guidelines for continuous education services. Rev Esc Enferm USP [Internet]. 2015 [cited 2018 Aug 2];49(6):991-8. Available from: http://www.scielo.br/pdf/reeusp/v49n6/0080-6234-reeusp-49-06-0991.pdf

10. Salunke S, Lal DK. Multisectoral approach for promoting public health. Indian J Public Health [Internet]. 2017 [cited 2018 Aug 2];61:163-8. Available from: http://www.ijph.in/temp/IndianJPublicHealth613163-5028782_135807.pdf 